PLAN OF STUDY FOR THE OHIO-INDIANA CARBONATEBEDROCK AND GLACIAL-AQUIFER SYSTEM

By Edward F. Bugliosi

U.S. GEOLOGICAL SURVEY

Open-File Report 90-151
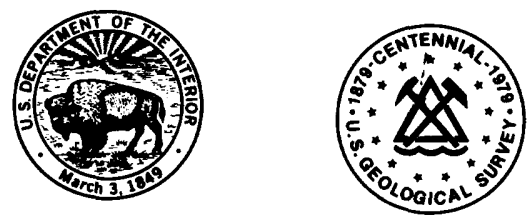

Columbus, Ohio 


\section{DEPARTMENT OF THE INTERIOR}

MANUEL LUJAN JR., Secretary

U.S. GEOLOGICAL SURVEY

Dallas L. Peck, Director

For additional information

Write to:

Chief, Ohio-Indiana RASA

U.S. Geological Survey

975 West Third Avenue

Columbus, $\mathrm{OH} 43212$
Copies of this Report can be Purchased from:

U.S. Geological Survey Books and Open-File Reports Box 25425, Federal Center Building 810 Denver, CO 80225 
Abstract 1

\section{CONTENTS}

Introduction 2

Purpose and scope 2

Study objective 6

Approach 6

Hydrogeologic setting 7

Bedrock geology 7

Glacial geology 8

Hydrologic setting 9

Glacial deposits 9

Carbonate bedrock 11

Regional ground-water flow 11

Regional geochemistry and water quality 13

Ground-water development 15

Plan of study 18

Data-base development and utilization 18

Definition of the hydrogeologic framework 18

Water-quality characterization and geochemistry 20

Ground-water-flow system analysis and digital modeling 21

Reports 22

Organization and staff 23

Work and report schedule 23

References cited 25

\section{ILLUSTRATIONS}

Figure 1. Map showing location of the Ohio-Indiana Regional-Aquifer Study Analysis (RASA) and adjacent RASA studies 3

2. Generalized bedrock geology map of the study area, location of geologic sections, and major physiographic provinces and structural features 4

3. Geologic sections showing structural features 5

4. Chart showing relations between geological and hydrologic units 8

5. Map showing major glacial deposits, limit of glaciation, and the course of the buried Teays River valley 10

6. Generalized, regional potentiometric surface in the carbonate bedrock aquifer 12

7. Map of Stiff diagrams showing chemical characteristics of water from selected wells in the carbonate bedrock aquifer 14

8. Graph showing ground-water withdrawals, by category 16

9. Map showing ground-water withdrawals 17

10. Schedule of major work activities 24 


\section{CONVERSION FACTORS AND ABBREVIATIONS}

For the convenience of readers who prefer metric (International System) units rather than the inch-pound terms used in this report, the following conversion factors are provided:

Multiply inch-pound unit

inch (in.)

foot (ft)

mile (mi)

square foot $\left(\mathrm{ft}^{2}\right)$

square mile $\left(\mathrm{mi}^{2}\right)$

acre

cubic foot per second per day $\left(\mathrm{ft}^{3} / \mathrm{s} / \mathrm{d}\right)$

cubic foot per second

$\left(\mathrm{ft}^{3} / \mathrm{s}\right)$

gallon per minute

( $\mathrm{gal} / \mathrm{min}$ )

million gallons per day

(Mgal/d)
By

25.4

0.3048

1.609

0.09290

2.590

0.4047

0.2447

28.32

0.06308

0.04381
To obtain metric unit

millimeter (mm)

meter (m)

kilometer $(\mathrm{km})$

square meter $\left(\mathrm{m}^{2}\right)$

square kilometer $\left(\mathrm{km}^{2}\right)$

square hectometer $\left(\mathrm{hm}^{2}\right)$

cubic hectometer $\left(\mathrm{hm}^{3}\right)$

liter per second

$(\mathrm{L} / \mathrm{s})$

liter per second

(L/s)

cubic meter per second $\left(\mathrm{m}^{3} / \mathrm{s}\right)$

Concentrations of chemical constituents and temperatures of air and waters are given in metric units. Concentration is given in milligrams per liter $(\mathrm{mg} / \mathrm{L})$. Milligrams per liter is a unit expressing the concentration of chemical constituents in solution as weight (milligrams) of solute per unit volume (liter) of solution (water). Water and air temperature is given in degrees Celsius $\left({ }^{\circ} \mathrm{C}\right)$, which can be converted to degrees Fahrenheit $\left({ }^{\circ} \mathrm{F}\right)$ by the following equation:

$$
\mathrm{F}=1.8(\mathrm{C})+32
$$

Sea level: In this report "sea level" refers to the National Geodetic Vertical Datum of 1929 (NVGD of 1929) - a geodetic datum derived from a general adjustment of the first-order level nets of both the United States and Canada, formerly called "Sea Level Datum of 1929". 


\title{
PLAN OF STUDY FOR THE OHIO-INDIANA CARBONATE-BEDROCK AND GLACIAL-AQUIFER SYSTEM
}

\author{
By Edward F. Bugliosi
}

\begin{abstract}
The major aquifers of a 35,000-square-mile area in western Ohio and eastern Indiana consist of Silurian and Devonian carbonate bedrock and Quaternary glacial deposits. These bedrock units and glacial deposits have been designated for study as part of the U.S. Geological Survey's Regional Aquifer-System Analysis program, a nationwide program to assess the regional hydrology, geology and water quality of the Nation's most important aquifers. The purpose of the study is to define the hydrology, geochemistry, and geologic framework of the aquifer system within the Silurian and Devonian rocks and glacial deposits, with emphasis on describing the ground-water-flow patterns and characterizing the water quality. The study, which began in 1988, is expected to be completed in 1993.
\end{abstract}

In 1980, the aquifers in the study area supplied more than 280 million gallons of water per day to industry, agriculture, and a population of more than 6.3 million people. With a projected future population growth to 7.1 million in 1990, and with intensified agricultural and industrial uses, water withdrawals from these bedrock and glacial aquifers are expected to be increased. The most significant ground-water problems in the study area result from the pronounced areal differences in availability and quality of the ground water. These differences are related to the lateral discontinuity of many of the glacial deposits and to variations in secondary permeability of the bedrock aquifers associated with patterns of fracturing.

Planned activities of the study include compilation of available geohydrologic and water-quality data, such as ground-water levels, geohydrologic properties of aquifers, chemical analyses, land-use and water-use data, and ancillary data such as digital satellite images. Additional geohydrologic and water-quality data may be collected from existing wells or wells that may be drilled for this study. A computerized, geographic information system will be used as a data base management tool and for spatial analysis and presentation of the data. A digital computer model will be developed to study the regional ground-water-flow system and to investigate the effects of development on the aquifer system. 


\section{INTRODUCTION}

The Regional Aquifer-System Analysis (RASA) program was initiated in 1978 (U.S. House of Representatives, 1977, p. 36-37) in response to National concern about the availability of ground water after a period of severe drought in the late 1970's. The regional aquifer system in Ohio and Indiana, consisting of Silurian and Devonian carbonate bedrock and Quaternary glacial deposits, is one of 28 regional aquifer systems that were identified to be studied by the U.S. Geological Survey (USGS) (Sun, 1986).

The study area of the Ohio-Indiana Carbonate Bedrock and Glacial Regional Aquifer-System Analysis project (herein referred to as the (Ohio-Indiana RASA) is about $35,000 \mathrm{mi}^{2}$ (square miles). The area extends approximately from Columbus, Ohio, to Indianapolis, Indiana, and from Lake Erie to the Ohio River (fig. 1), and includes about half the area of each State. The area lies between the Appalachian Plateau physiographic province to the east, the Illinois structural basin to the west, and the Michigan structural basin and Lake Erie to the north, and is mostly within the Central Lowlands physiographic province east of the Mississippi River (Fenneman, 1938).

The study will focus on the carbonate-bedrock aquifers in Silurian and Devonian rocks and the overlying glacial deposits within the area. The lower stratigraphic boundary is most likely coincident with relatively impermeable shales and mixed carbonate and fine clastic rocks of Late Ordovician age, except near the central part of the southern boundary of the study area where these confining bedrock units are locally discontinuous.

The subcrop limit of the carbonate bedrock aquifer beneath the glacial deposits is shown in figure 2. The lateral boundaries of the carbonate-bedrock and glacial-aquifer system in the study area will be arbitrarily designated by the approximate location of the $10,000 \mathrm{mg} / \mathrm{L}$ (milligram per liter) chloride concentration in ground water, disregarding the continuity of the bedrock aquifer, which dips to the east, west, and north into the Appalachian, Ilinois, and Michigan structural basins, respectively (figs. 2 and 3). The $10,000 \mathrm{mg} / \mathrm{L}$ chloride concentration is used because very little fresh ground water moves across this boundary; otherwise, this high chloride concentration could not exist.

\section{Purpose and Scope}

The purpose of this report is to present a systematic plan for investigating the carbonate-bedrock and glacial-aquifer system in western Ohio and eastern Indiana. More specifically, it outlines the carbonate bedrock and glacial aquifer system in terms of (1) the hydrogeologic framework of the aquifers, (2) the present ground-water-flow system, (3) the present water chemistry and the geochemical basis for that chemistry, and (4) withdrawals from the aquifers and their hydrologic response to development. 


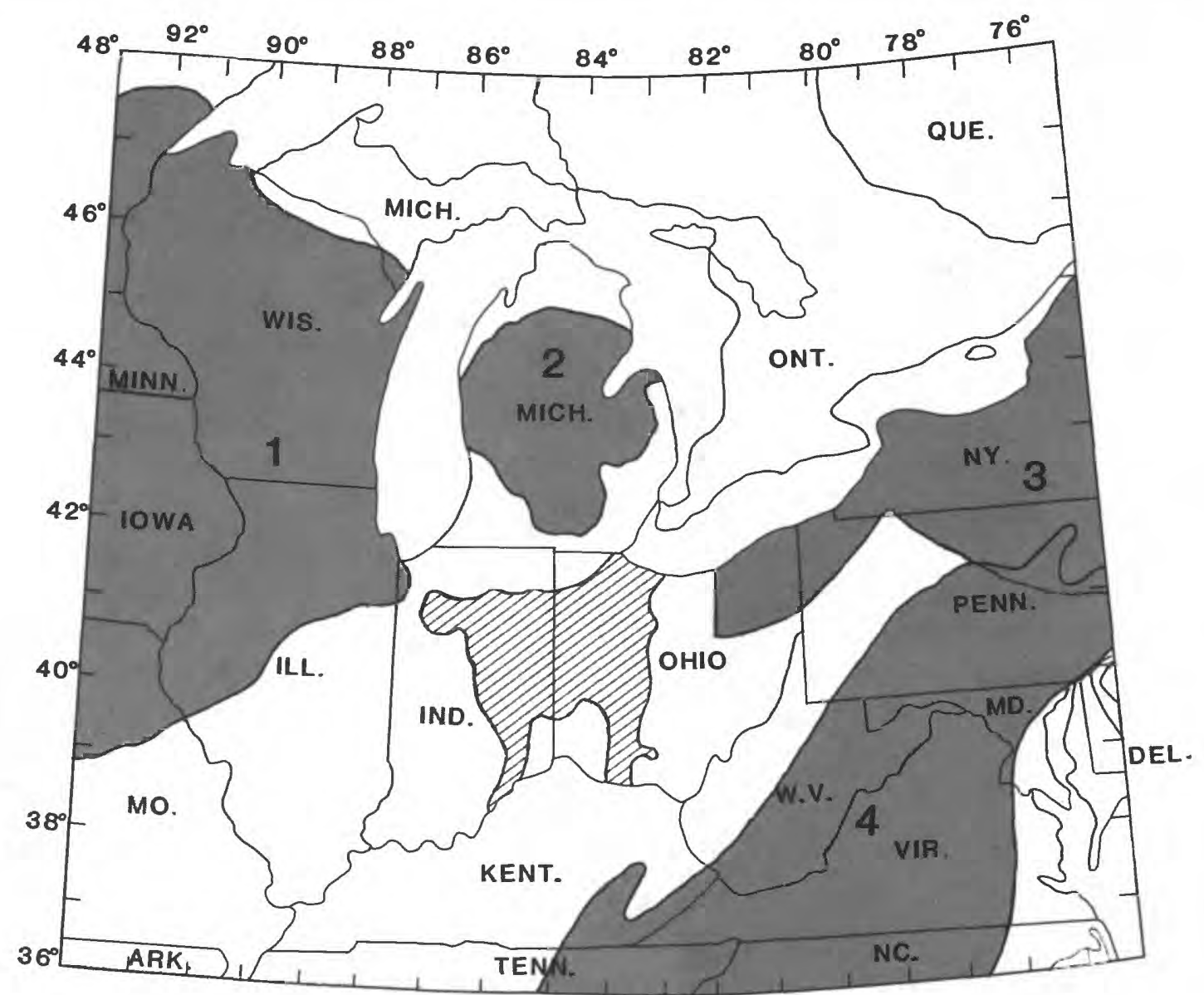

Base From U.S. Geological Survey

State Base Maps, 1973, 1971.

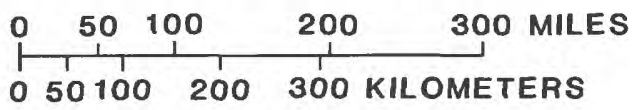
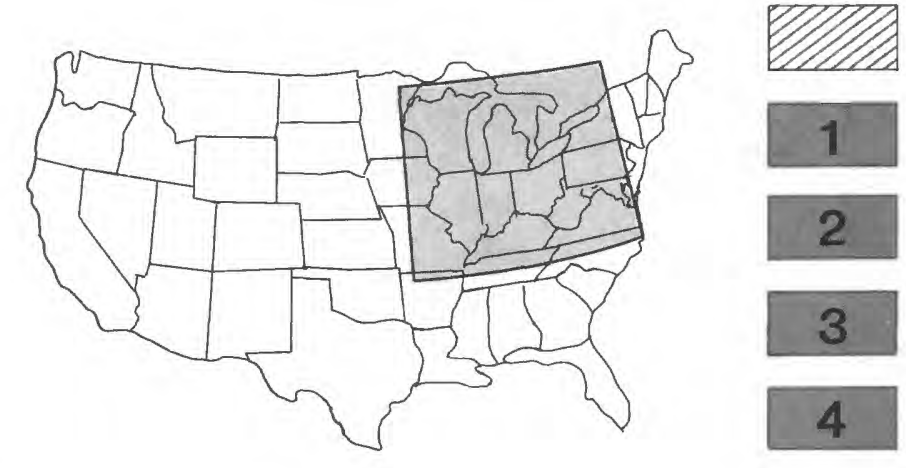

EXPLANATION

RASA STUDY AREAS Ohio-Indiana Carbonate and
glacial deposits

Nothern Midwest

Michigan Basin

Northeast Glacial Valleys

Appalachian and Piedmont areas

Figure 1.--Location of Ohio-Indiana Regional Aquifers System Analysis (RASA) project and adjacent RASA studies. 


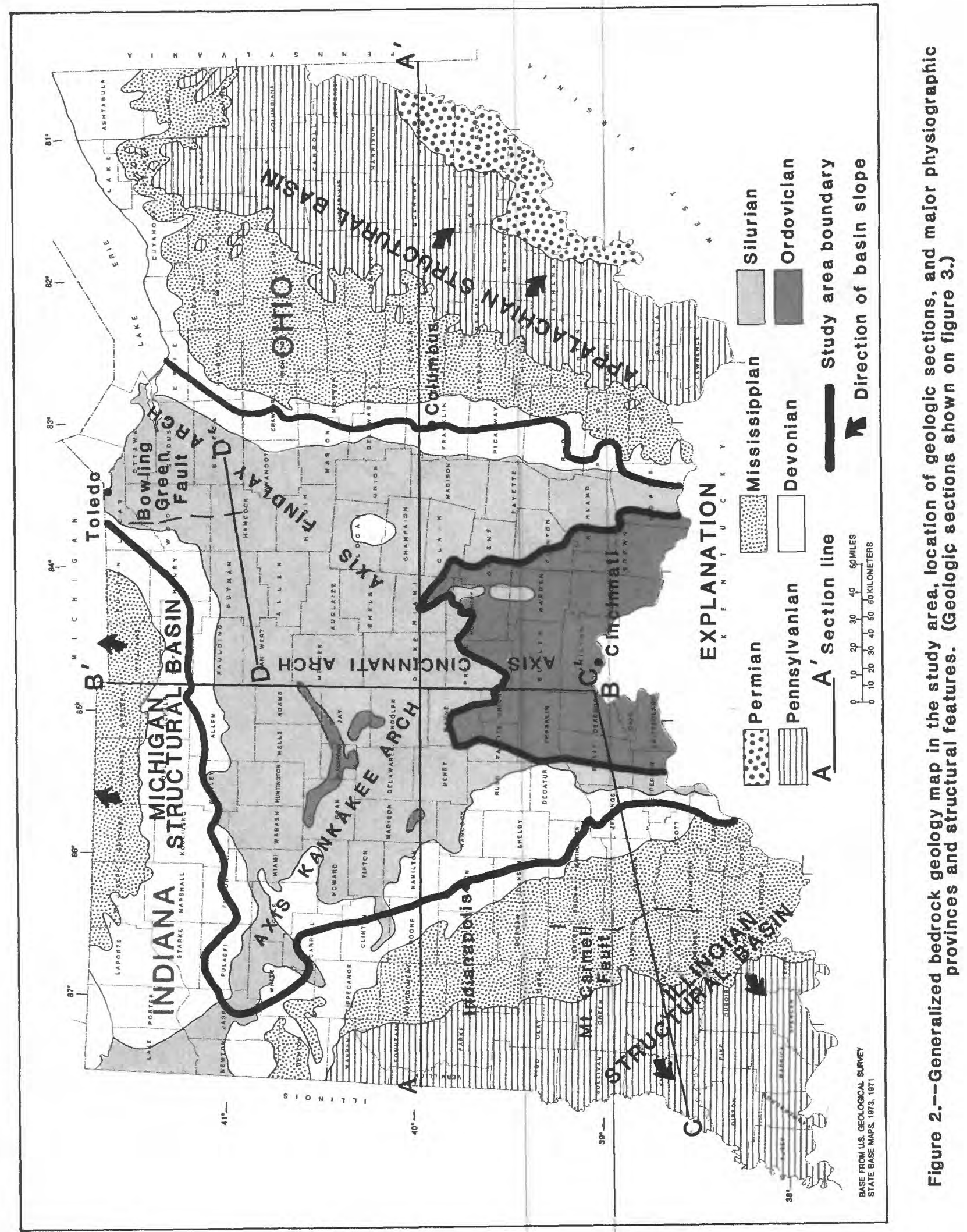




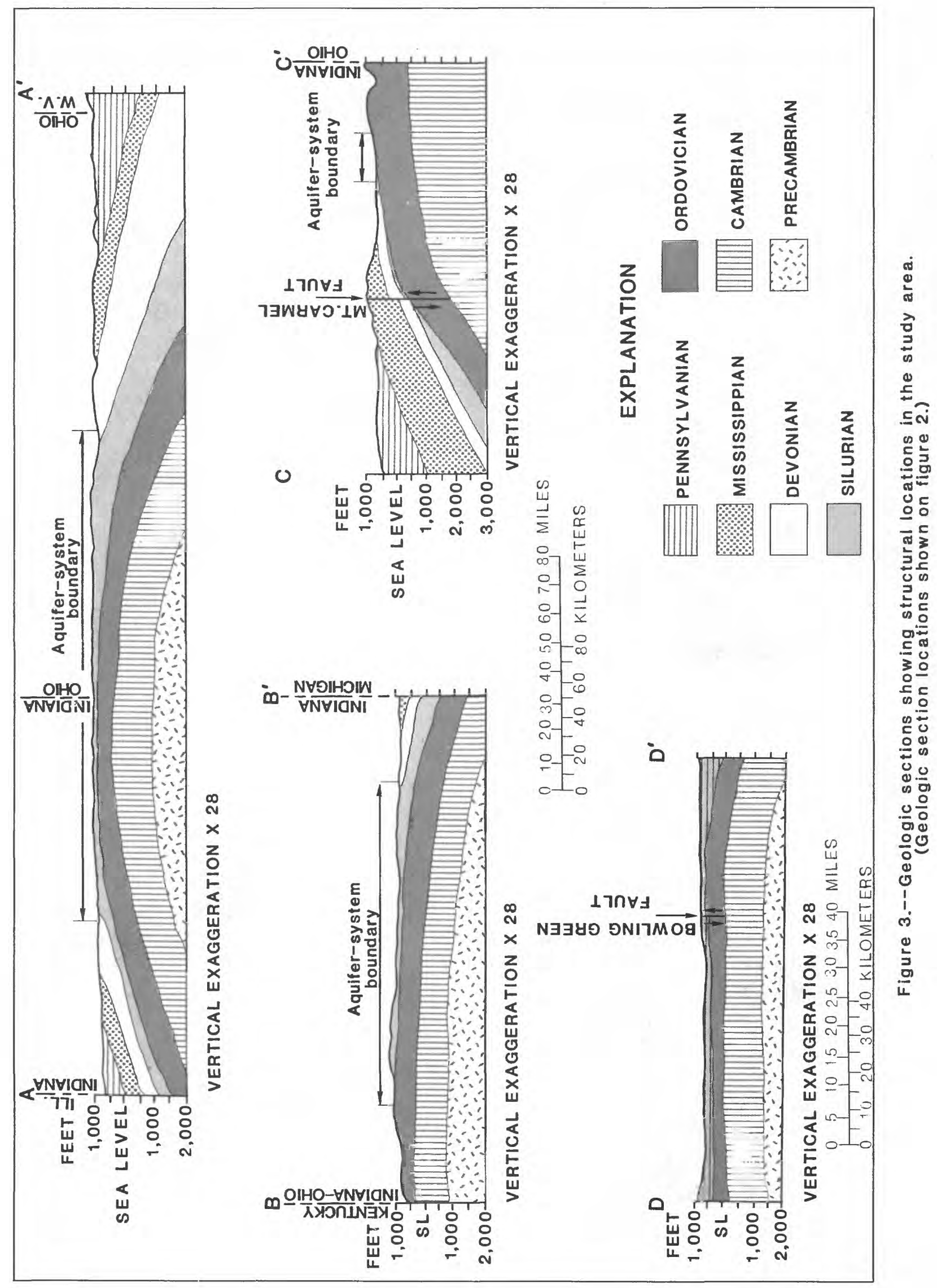


Aquifers within the carbonate bedrock and the overlying glacial deposits will be examined as an interconnected, regional system. Smaller, individual flow systems will be studied in detail only where they are hydrologically important to the overall understanding of the larger, regional system.

\section{Study Objectives}

The major objective of the study is to describe the geohydrology, geochemistry, and ground-water flow in the aquifer consisting of carbonate rocks and glacial deposits in western Ohio and eastern Indiana. More specifically, the study will attempt to:

1. Describe the regional ground-water-flow system, including its lateral and vertical hydrologic boundaries, areas of regional recharge and discharge, and regional relations between surface water and ground water.

2. Categorize the chemistry of the ground water, delineate water-chemistry patterns in the major aquifers, and relate the patterns to geochemical processes and the flow system where possible.

3. Conceptualize the flow pattern on the basis of available geohydrologic and geochemical information.

4. Evaluate the hydrologic effects of water withdrawals from the aquifers.

\section{Approach}

The study objectives will be met by use of available data to the greatest extent possible. Because the study area is relatively large, it would not be feasible to collect all the field data needed to analyze such a large and complex system. However, because of the large amount of available data, only a limited amount of additional data may be needed, and can be obtained by the drilling of test wells, collection and analysis of water samples, and geophysical exploration.

Specifically, the approach includes the following elements:

1. Compilation and analysis of existing geologic, hydrologic, water-chemistry and pumpage data. 
2. Development of a digital data base from the available and compiled information using a geographic-information system.

3. Development of a ground-water-flow model on the basis of the compiled data. The model will be used to understand the aquifer behavior and to evaluate the effects of ground-water development on the aquifers.

4. Determination of spatial and temporal trends in water quality in the aquifers.

5. Collection and analysis of additional data, where needed, to improve and refine the developed model for aquifer analysis.

6. Use of geochemical models and maps showing distribution of chemical characteristics to define the process responsible for the areal differences in ground-water quality.

7. Documentaion of the chemical evolution of ground water as it moves from areas of recharge to areas of discharge, and correlation of this chemical evolution with results of the flow model, if sufficient chemical data are available.

The approach emphasizes the factors necessary to describe the geohydrologic and geochemical characteristics of the aquifers and to define the problems associated with the development of the ground-water resources.

\section{HYDROGEOLOGIC SETTING}

\section{Bedrock Geology}

The stratigraphic sequence in the study area progresses upward from a base of Precambrian granites and gneisses to Devonian shales and carbonate rocks in the southcentral part (figs. 2 and 3 ). The carbonate-bedrock aquifer is composed predominantly of limestone and dolomite of Silurian and Devonian age. The aquifer is underlain by a sequence of Upper Ordovician shale and fine clastic rocks overlain by a thick sequence of Upper Devonian shale (fig. 4 in back of report).

Regional structural features include the Cincinnati, Findlay and Kankakee arches and the Bowling Green fault (fig. 2). The Cincinnati arch extends from near Cincinnati, Ohio, northwestward into southeastern and central Indiana. The Findlay arch extends 
from north of Cincinnati, northeastward toward Lake Erie. These arches mark a structurally high region that separates the Appalachian structural basin to the east, from the Michigan structural basin to the northwest, and the Illinois structural basin to the west (fig. 2). The Kankakee arch is an extension of the Cincinnati arch into northeastern Indiana. The Bowling Green fault has a maximum displacement of about $200 \mathrm{ft}$ (feet) in northwestern Ohio (Ohio Department of Natural Resources, 1970).

The Devonian bedrock is predominantly limestone that exhibits karst features in some areas. The unconformity between the Lower and Middle Devonian may have significant hydrologic implications because of differences in depositional environments between units. Thick shale units in the Upper Devonian mark the upper geohydrologic boundary of the bedrock-aquifer system around the northern, eastern, and western margins of the Silurian and Devonian subcrop area (fig. 4).

Silurian rocks in the study area are predominantly limestone and dolomite interbedded with thin beds of shale and gypsum. The carbonate beds are typically massive, crystalline dolomite that grades locally into reef structures. Brecciated dolomites, shaly dolomites, and fossiliferous and cavernous limestone and dolomite also are present as a result of variable depositional environments and postdepositional erosion and weathering.

The lower stratigraphic and geohydrologic base of the bedrock aquifer system is located in the Upper Ordovician rocks. The basal boundary consists of undifferentiated Cincinnatian rocks in northwestern and west-central Ohio and the Maquoketa Group (Shaver and others, 1988) in Indiana (fig. 4). These units are mostly shale and cherty and (or) argillaceous limestone and fine clastic rocks that act hydrologically as the lowermost confining unit of the bedrock aquifer system.

The bedrock surface within the study area has been modified by erosion and dissolution of the predominantly carbonate rocks. The surface ranges from nearly flat to hilly. Preglacial uplands and valleys have been modified by Pleistocene glacial activity . Sinkholes and other karst features are present, especially in the Devonian units in the northeastern part of the study area and in southern Indiana.

\section{Glacial Deposits}

The entire study area has been glaciated except for a small part of the southeast (fig. 5). Surficial deposits in the study area consist mostly of till and morainal material, lake deposits along Lake Erie, and outwash deposits interspersed throughout the area (fig. 5). Generally, the glacial deposits are less than 25 feet thick in northeastern Indiana and northwestern Ohio along Lake Erie, thickening, on the average, from 25 to 75 feet over the remaining areas to the south in Ohio (Stout, 1941) and more than 150 feet in much of central and south-central Indiana (Wayne, 1956). 
The pre-Pleistocene Teays River system, which drained the region currently drained by the Ohio River, is a series of buried valleys, the main stem trending northwestward in eastern Ohio, westward in western Ohio and eastern Indiana, and continuing southwest toward the Mississippi Embayment (Flint, 1956) (fig. 5). The valley walls are steep, and the valley floor is commonly more than 350 feet below the adjacent bedrock surface in much of the study area. In west-central Ohio, the valley is commonly more than 3,000 feet wide and is cut into Silurian limestone and dolomite. In much of eastern Ohio the valley is filled with fine-grained lake deposits or till. However, in places in Ohio and in much of Indiana, basal deposits consist of sand and gravel. There, the valley-fill deposits are productive aquifers and wells drilled into them are capable of sustained yields of more than $1,000 \mathrm{gal} / \mathrm{min}$ (gallons per minute).

\section{HYDROLOGIC SETTING}

The hydrology of the glacial-and carbonate-bedrock aquifers in the study area has not been studied regionally, and data are lacking in many areas. Much of the bedrock hydrogeologic data are derived from geophysical logs of oil and gas wells in northcentral Ohio and east-central Indiana.

The hydrogeology of the glacial deposits is known only on a local scale in both States. Hydraulic data for the glacial deposits associated with the buried Teays Valley and its tributaries in Ohio generally are available only where ground water in the deposits is being used for municipal or large-scale private water supply. However, in much of Indiana, the geometry of the main valley has been well documented by the Indiana Geological Survey in a series of maps (Burns and Others, 1985)

\section{Glacial Deposits}

The glacial deposits in the study area have a wide range of hydraulic characteristics because of variations in texture and lithology. Locally, hydraulic conductivities can differ by several orders of magnitude, even within the same type of deposit. Regionally, differences in hydraulic conductivity between lake deposits, till, and outwash can cause differences in rates of movement of ground water as well as the amount of vertical leakage into the carbonate-bedrock aquifer.

Transmissivities for outwash in central Indiana range from 10,000 to $28,000 \mathrm{ft}^{2} / \mathrm{d}$ (feet squared per day) (L.D. Arihood, U.S. Geological Survey, written commun., 1989), whereas transmissivities for sand and gravel in central Ohio range from 10,000 to 12,000 $\mathrm{ft}^{2} / \mathrm{d}$ (K. Breen, U.S. Geological Survey, oral commun., 1989). The vertical hydraulic conductivity of clay-rich till throughout the study area will influence the rate of recharge 


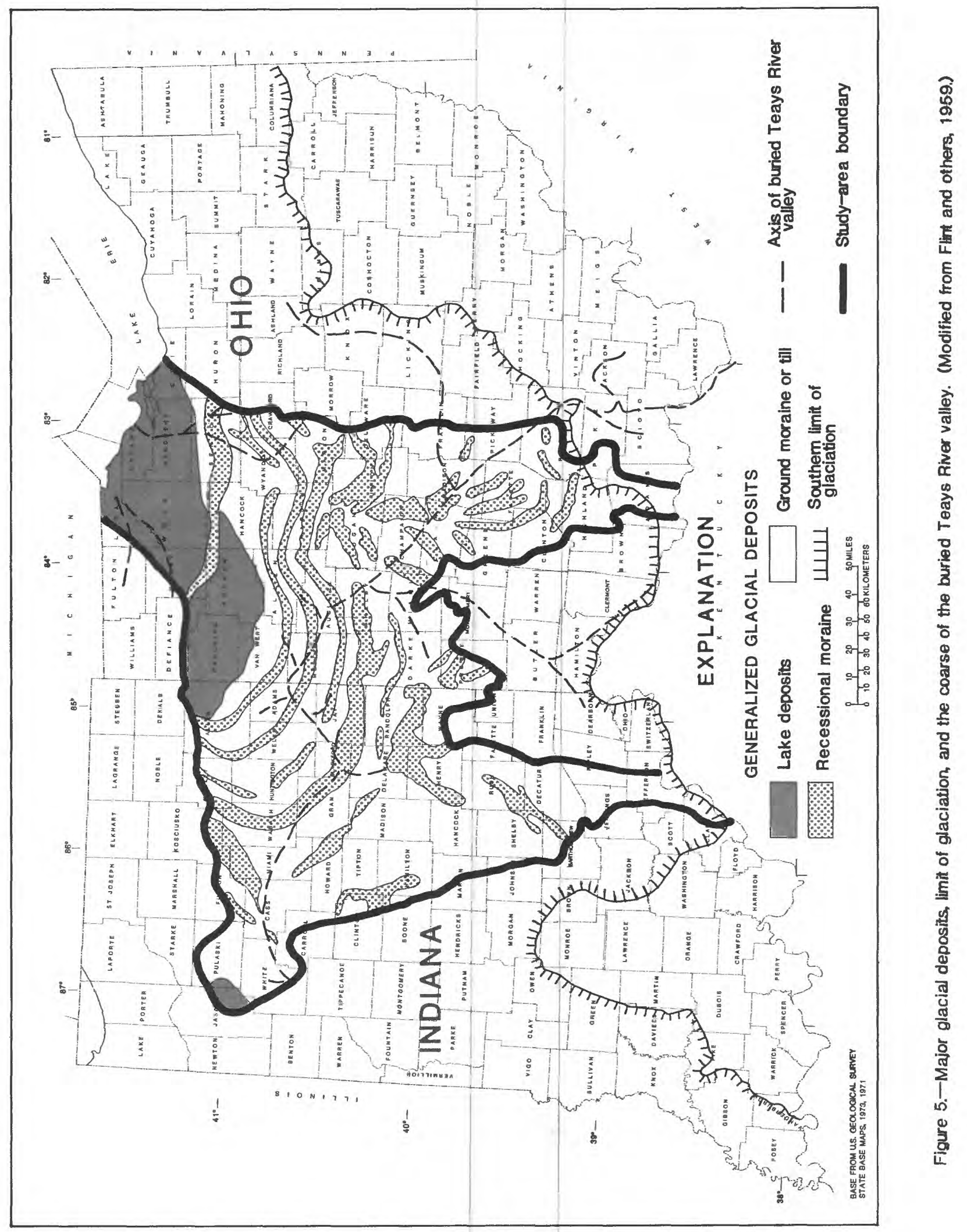


to the underlying bedrock aquifers. Vertical hydraulic conductivities for till in central Indiana range from $7.0 \times 10^{-2}$ to $7.0 \times 10^{-6} \mathrm{ft} / \mathrm{d}$ (feet per day) (L.D. Arihood, U.S. Geological Survey, written commun., 1989).

\section{Carbonate Bedrock}

The permeability in the carbonate bedrock aquifer is primarily secondary permeability - a direct result of dissolution along joints, fractures, and bedding planes. The variable pattern of these secondary permeabilities has made location of significant water supplies unpredictable. For example, well yields from the upper part of the Lockport Dolomite and Bass Islands Dolomite in Ohio (fig. 4) range from less than 25 to $1,000 \mathrm{gal} / \mathrm{min}$ over distances of less than a few thousand feet. Properly constructed wells in the carbonate-bedrock aquifer generally have yields from 10 to $2,000 \mathrm{gal} / \mathrm{min}$ in the study area.

Transmissivity of the carbonate bedrock aquifer ranges from 70 to $25,000 \mathrm{ft}^{2} / \mathrm{d}$ in Ohio (Ohio Department of Natural Resources, 1970) and from 500 to $10,000 \mathrm{ft}^{2} / \mathrm{d}$ in Indiana (Arihood, 1982). Average transmissivity values for the carbonate bedrock in western Ohio have been reported to be 3,300 $\mathrm{ft}^{2} / \mathrm{d}$ (Ohio Department of Natural Resources, 1970), 3,000 $\mathrm{ft}^{2} / \mathrm{d}$ (Planert, 1980), and from 1,000 to 2,000 $\mathrm{ft}^{2} / \mathrm{d}$ for counties in central Indiana (L.D. Arihood, U.S . Geological Survey, written commun., 1989). These values represent local conditions and may not be representative of the overall range of transmissivities of the carbonate bedrock aquifer on a regional basis.

\section{Regional Ground-Water Flow}

The direction of the regional ground-water flow is generally toward the major streams and toward Lake Erie (fig. 6). The major component of horizontal flow in the carbonate-bedrock aquifer is across surface-water divides. However, preliminary modeling attempts (L.D. Arihood, U.S. Geological Survey, oral commun., 1989) indicate that flow in the confined part of the bedrock aquifer is considerably less than flow resulting in discharge to major streams and Lake Erie. The carbonate-bedrock aquifer commonly is confined by low-permeability tills and (or) shales (fig. 5). However, it is unconfined locally where it is incised by the buried Teays River valley or is covered by only a thin layer of drift.

Ground-water flow in glacial deposits generally involves local recharge and discharge within surface-water basins. The glacial aquifers generally are unconfined, except where outwash deposits or basal material in the buried Teays River valley are covered by till or fine-grained lake deposits. 


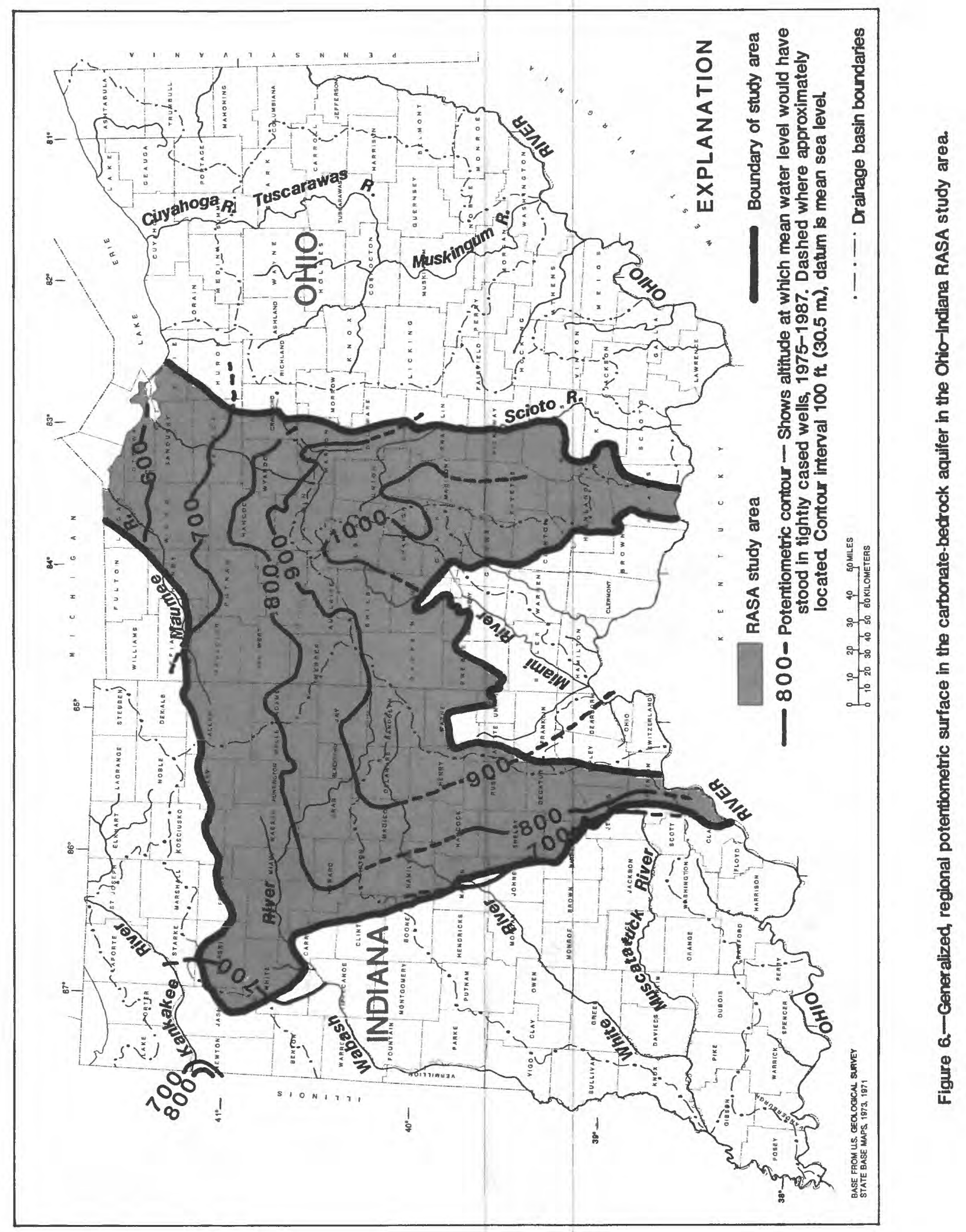


Average recharge available to the carbonate bedrock aquifer has been estimated to be $6 \mathrm{in} / \mathrm{yr}$ (inches per year) in Ohio and 3 to $3.6 \mathrm{in} / \mathrm{yr}$ in Indiana (Norris, 1969, and Indiana Governor's Water Resource Study Commission, 1980). Recharge to the bedrock aquifer occurs mainly as diffuse downward leakage through the overlying glacial deposits or as direct recharge where bedrock is exposed at the surface.

Major faulting in the study area (fig. 3) locally influences ground-water-flow patterns, especially near the Bowling Green fault. However, it is not anticipated that the Bowling Green fault or other smaller faults within the study area will affect the overall regional flow pattern.

\section{Regional Geochemistry and Water Quality}

Water in the glacial deposits circulates within a short distance between areas of recharge and discharge; therefore, the quality of water in glacial deposits is good, with low concentrations of dissolved solids, relative to water in the bedrock aquifer. Water in the carbonate-bedrock aquifer is generally very hard and either a calcium bicarbonate or calcium sulfate type. The bicarbonate waters probably are derived from the dissolution of carbonate rocks, whereas the sulfate waters are likely a result of dissolution of gypsum commonly present in the Silurian and Devonian rocks in the study ared. Figure 7 provides a general summary of ground-water-chemical types in the carbonate-bedrock aquifer throughout the study area.

Results of previous studies indicate that the total-dissolved-solids and sulfate concentrations in ground water from the carbonate-bedrock aquifer tends to increase as the water flows through the aquifer system (Ohio Department of Natural Resources, 1970). These results suggest that the regional movement of ground water can be documented by the change in chemical constituents.

Norris and Fiddler (1971) reported that ground water in northwestern Ohio is undersaturated, with respect to calcite, in highly permeable zones, and they postulated that hydrogen sulfide may increase in the direction of the water movement. They also concluded that concentrations of calcium, bicarbonate, chloride, sulfate, and total dissolved solids increase, and that the ground water changes from a calcium bicarbonate type to a calcium sulfate type as ground water moves from areas of recharge to areas of discharge. However, it is not known if these water-quality trends are regional in nature.

Saline ground water (water containing greater than $1,000 \mathrm{mg} / \mathrm{L}$ total dissolved solids) is reported to be found at average depths of about 450 feet in the study area (Todd, 1980 , p. 310-311). Brines, associated with oil- and gas-producing units stratigraphically beneath the Silurian carbonate rocks have reportedly entered the carbonate bedrock 


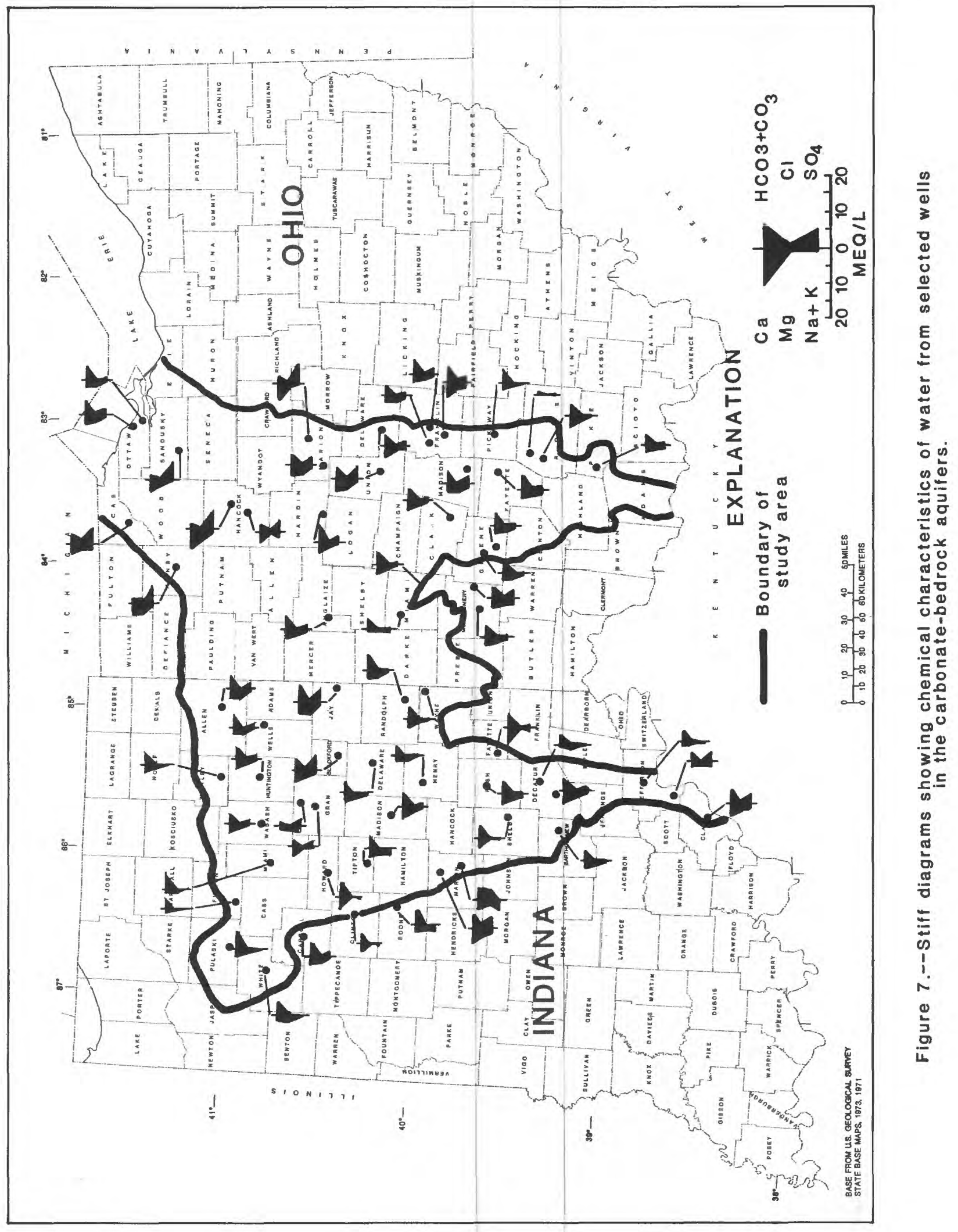


aquifers in areas with historically high petroleum-production rates (W. Steen, Indiana Department of Natural Resources, Division of Water, oral commun., 1988). It is not known whether this is the result of induced upconing by pumping or due to natural hydraulic gradients between the carbonate-bedrock aquifer and the underlying, brinecontaining formations.

\section{GROUND-WATER DEVELOPMENT}

Ground-water withdrawals for 1980 in the study area can be summarized by the major categories of industrial, rural, and public supply (fig. 8). For discussion purposes, the study area has been divided into 13 small areas on the basis of land use (fig. 9). In 1980 , more than $280 \mathrm{Mgal} / \mathrm{d}$ (million gallons per day) of ground water was withdrawn from the carbonate bedrock and glacial aquifers. The Indiana Committee on Existing and Projected Water Uses and Needs (1978) estimated that, by the year 2000, withdrawals in Indiana would increase by 65 percent. Water use in Ohio can also be expected to increase.

Figure 8 represents the total ground-water use for the year 1980. The largest single ground-water use is for public supply. The central and south-central part of the study area (areas 3, 5, 8, and 10 in fig. 9), including Indianapolis, Columbus, and Dayton, accounted for the largest amount of ground-water pumpage for public supply.

An estimated $91 \mathrm{Mgal} / \mathrm{d}$ was withdrawn in 1980 for rural, domestic, and livestock purposes. This amount was equally distributed over the study area, with the exception of the western part (areas 8,10, and 13 in fig. 9). where ground-water use amounted to about 50 percent more than the average used in all remaining areas.

Estimated industrial use was about $80 \mathrm{Mgal} / \mathrm{d}$ in 1980 . The greatest use was in area 4 in south-central Ohio. Although most industries depend on surface-water supplies for most of their needs, ground water becomes important as industry expands to areas where surface water is not available.

Data for ground-water withdrawals for irrigation are sparse, especially for Ohio, but information from the U.S. Department of Agriculture (1984a and 1984b) indicates that about $60 \mathrm{Mgal} / \mathrm{d}$ was withdrawn in 1982. Areas 1, 3, and 13 (fig. 9) were the areas of the largest use, although only 0.2 percent of all farmland was irrigated with ground water. If drought conditions similar to those in the summer of 1988 recur, an increasing number of farms will turn to irrigation from ground-water sources during critical growing periods, and new stress may be put on the aquifers. 


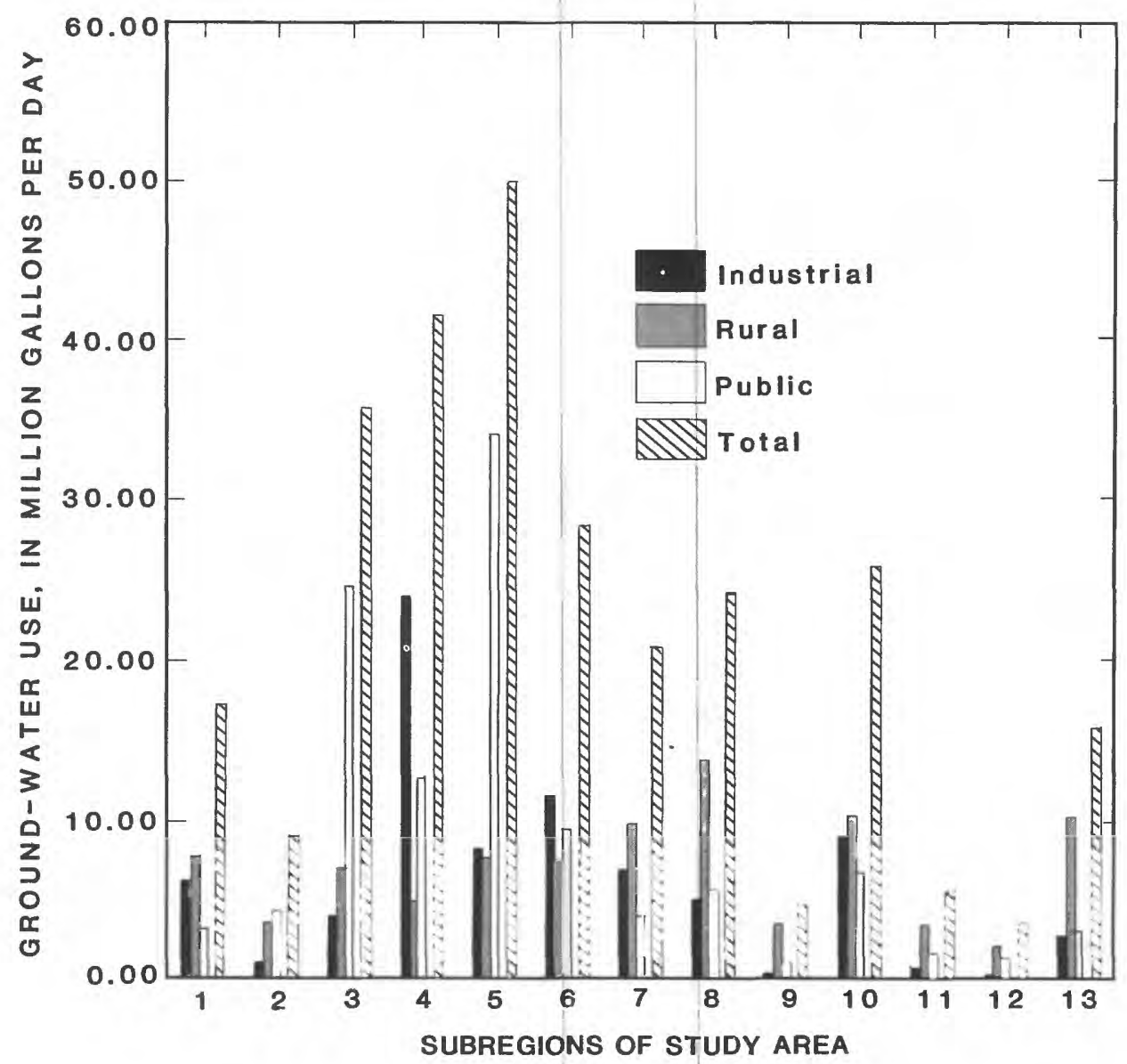

Figure 8.--Ground-water use, by category, in subregions of the Ohio-Indiana RASA study area. 


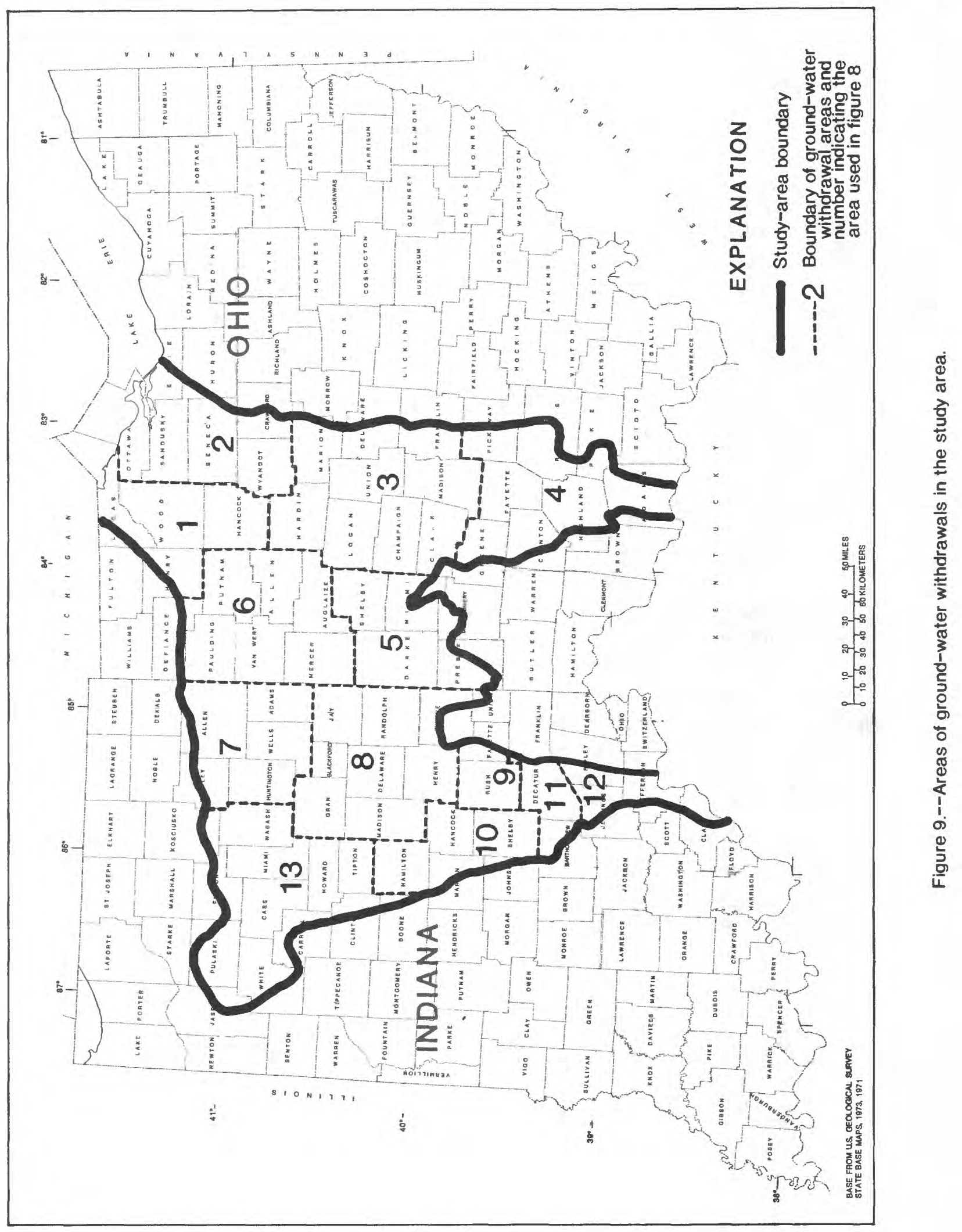




\section{PLAN OF STUDY}

The major tasks that will be accomplished during the course of the study are discussed below. These tasks entail five areas of effort.

\section{Data-Base Development and Utilization}

The development of a systematic data base is crucial to the study. A Geographic Information System (GIS) will be used as a data-base-management tool and as a means to help interpret and present the data graphically. The principal software to be used will be ARC/INFO'.

A GIS approach to data management will allow integration of point data and the areal representation of geohydrologic, geochemical, and water-quality patterns. The approach also will allow more efficient integration of data from State and other Federal agencies because some of these agencies are using compatible GIS formats for their data storage.

\section{Definition of Hydrogeologic Framework}

Information on the stratigraphy, water-bearing zones and confining units in the Paleozoic bedrock, and the geometry of the buried Teays River valley and major buried tributaries will be obtained from available borehole geophysical logs, surface-geophysical data, oil-, gas-, and water-well logs. Sources of data will be the USGS computerized data bases; the Indiana and Ohio Departments of Natural Resources and Geological Surveys; other Federal agencies, such as the U.S. Environmental Protection Agency, U.S. Department of Agriculture, and Soil Conservation Service; and reports of these agencies, University dissertations, and private consultants.

A method will be devised to enter the data into the GIS data base. The use of scanning technology and development of software in conjunction with digitizing will expedite data entry and creation of a usable data base.

The use of lineament analyses from digital, remotely sensed satellite data may help to define areas of differing fracture density within the bedrock. Data from these analyses will then be incorporated into the GIS data base and compared with hydrologic and geologic interpretations and analyses and water-quality and geochemical data trends for further spatial analyses.

${ }^{1}$ Use of a brand name in this report is for identification purposes only and does not constitute endorsement by the U.S. Geological Survey. 
Throughout most of Indiana, the buried Teays valley has been mapped by the Indiana Geological Survey. Data for the buried valley in Ohio are lacking for many areas. The extent of the valley and the nature of its deposits in Ohio may need to be delineated by examination of water-well and geophysical logs and (or) use of surfacegeophysical methods.

The hydrogeologic data will be used to prepare maps and produce cross sections that delineate the aquifer boundaries and confining units, indicate facies changes throughout the carbonate aquifer that may control transmissivity variations, and define the geometry of the buried Teays River valley and its major tributaries and the thickness of highly permeable, unconsolidated deposits within the valleys.

Specific products that will be produced from these data sets will include, but not be limited to:

1. Isopach maps that show the areal extent and thickness of the bedrock aquifers;

2. Structure-contour maps of tops of the major water-bearing zones and confining units in the bedrock;

3. Geohydrologic sections and fence diagrams of the bedrock aquifers and confining units;

4. Bedrock fracture-trace maps that show trends of major fracture zones and possible anisotropy patterns, and maps that show karstic regions;

5. Maps that show the thickness of stratified drift and generalized types of surficial glacial deposits; and

6. Isopach maps of the major permeable unconsolidated aquifer deposits within the buried Teays River valley and its tributaries.

In addition to the compilation and analyses of the above-mentioned data, other types of data such as aquifer-test analyses, shut-in-pressure data from oil- and gas-drillstem tests, stream gain-loss data, and low-flow stream analyses and ground-water-level data, will be compiled and analyzed to determine hydraulic properties of the major waterbearing and confining bedrock units, for the major unconsolidated deposits within the buried Teays River valley system, and, in general, for the major glacial deposits. 
Analyses of the hydrogeologic data will help estimate values for vertical and horizontal hydraulic conductivity, transmissivity, water table and potentiometric-surface altitudes, and current and potential well yield. These data will also be used to determine the relation between the aquifer material in the buried Teays River valley channels and the carbonate-bedrock aquifer into which these channels cut, and will also help estimate the permeabilities of the major surficial, glacial deposits.

The principal products that will be generated from analyses of these hydraulic data will include, but not be limited to:

1. Transmissivity maps of the glacial and bedrock aquifers;

2. Maps of potential well yields;

3. Water-table and other potentiometric surface maps.

\section{Water-Quality Characterization and Geochemistry}

A general categorization of the chemistry of water in the carbonate bedrock and glacial aquifers will include examination of available data that contain, at a minimum, values for major cation and anions, temperature, $\mathrm{pH}$, and specific conductance or totaldissolved-solids concentrations. Other chemical constituents also will be examined to help the Ohio-Indiana RASA staff analyze the geochemical equilibrium of the ground water as it flows from areas of recharge to discharges. Such constituents may include trace metals and stable isotopes.

Chemical analyses of water from the USGS's National Water Data Storage and Retrieval System (WATSTORE) and pertinent analyses from other Federal agencies, such as the USEPA, and other State and county agencies will be examined for reliability, and suitable data will be entered into the water-quality and GIS data bases. Most chemical analyses from State agencies may not be as complete as the data stored in the USGS WATSTORE data base; however, they may help determine trends for some characteristics such as hardness and concentration of total-dissolved-solids.

Products to be developed from the water-quality data will include maps of hydrochemical facies and distribution of major ions and stable isotopes.

The need for collection of additional water chemistry data will be evaluated after an initial analysis of the available ground-water data. It is almost certain that, at the least, additional stable-isotope data will have to be collected. 
Additional water samples will be collected from existing wells where geologic control has been established, and where representative samples can be obtained from individual aquifers or water-bearing zones. It may be necessary either to pack off specific intervals in existing wells to sample individual water-bearing zones, or to drill new wells in areas where wells are not available for sampling individual zones. If new wells are drilled, the drilling will be designed to provide geohydrologic data as well as the water-quality and geochemical data.

The geochemical modeling efforts will entail analysis of mineralogic data of the aquifer materials and water-chemistry data. This modeling effort will be used to (1) evaluate the reliability of the mapped geochemical facies of the water in the carbonate bedrock and glacial aquifers, (2) help explain the origin and chemical evolution of water in various parts of the aquifers, and (3) substantiate the findings of the flow directions and rates resulting from the ground-water flow model. The geochemical analyses will also be used to help explain the areal differences in water quality throughout the regional system.

\section{Ground-Water-Flow-System Analysis and Digital Modeling}

Base-flow data for major rivers in the study area generally are available. Regression analyses of these data will be used to determine the relative amounts of groundwater discharge from the glacial aquifer and the bedrock aquifer. If warranted, stream gain-loss measurements will be conducted. The base-flow and (or) low-flow data will give an indication of regional ground-water discharge to the surface-water system, and will be used to calibrate the steady-state model.

Flow in the carbonate bedrock aquifer will be analyzed by use of potentiometricsurface maps of the bedrock aquifer. Hydraulic-head distribution in the glacial deposits will also be considered with respect to the amount of recharge and the leakage that enters the bedrock aquifer.

Published potentiometric-surface maps of parts of the bedrock and glacial aquifers will be examined along with individual hydraulic-head data. Much of the head data will need to be carefully evaluated because many wells are open to more than one aquifer or water-bearing zone, and may represent composite heads. A systematic, statistical approach will be developed to help determine the usefulness of such data in compiling potentiometric surface maps. Also, potentiometric surface maps will be produced from well data that represent different thicknesses of the bedrock aquifer, and by comparison of these potentiometric surface maps an understanding of, at least, the relative contribution of different water-bearing zones to the overall flow system will be evaluated. 
The buried Teays River valley system is an integral part of the regional aquifer system. It is filled with appreciable amounts of saturated sand and gravel in areas, and is likely to respond as either a recharge or discharge area in relation to the surrounding bedrock, depending on head differentials in each. However, in certain areas of Ohio the buried Teays valley is filled with fine-grained lacustrine sediment and will act as a barrier to ground-water flow. The buried Teays River Valley and its hydraulic interaction with the carbonate bedrock aquifer will be investigated.

A preliminary, steady-state model will be developed as soon as sufficient data are gathered and incorporated into the GIS data base. This model will help test the conceptualization of the aquifer system and will serve as a basis for evaluation of data deficiencies. The initial steady-state model will also be used to determine additional waterquality data-collection, and location of flow paths from which geochemical models will be developed.

Because little irrigation occurs within the study area and population is concentrated in and around a few large cities that use large quantities of surface water as their water supply, there are no large-scale regional pumping stresses on the ground-water flow system in 1989. Because of this, development of a regional transient model is not anticipated at this time. However, transient flow-models may be developed for subregional agricultural areas where significant pumpage occurs, (such as in northwestern Indiana) to improve an understanding of hydraulic effects of aquifer development in those areas.

\section{Reports}

It is planned that the final results of this study will be presented, as have the results of other RASA studies, in a series of USGS Professional Papers to be prepared at the conclusion of the study. Topical papers on geohydrologic and geochemical aspects, flow-model and geochemical-model analyses, and water-use data will be prepared during the course of the study as data are collected and analyzed. These papers will be submitted for publication in other USGS series of reports such as Open-File Reports, WaterResources Investigations Reports, and Hydrologic Atlases, in journal articles and (or) scientific conferences.

The Professional Paper series will consist of four chapters;

A. Summary of the carbonate-bedrock and glacial-aquifers.

B. Hydrogeologic framework of the carbonate-bedrock and glacial-aquifers. 
C. Ground-water hydraulics and simulation of regional flow in the carbonate bedrock and glacial aquifers.

D. Geochemistry and water quality of the carbonate bedrock and glacial aquifers.

\section{Organization and Staff}

The project staff will consist of four hydrologists located in Columbus, Ohio. The staff will include (1) a project chief who will be responsible for planning, organization, and daily operation of the project, and for the summary report, and helping with the preparation of the hydrogeologic framework; (2) a hydrologist responsible for hydrologic data analysis, flow modeling, and the major contribution to the hydrologic and hydraulic analysis; (3) a geochemist/hydrologist responsible for the water-quality and geochemical aspects of the study, and (4) a hydrologist/geologist who will be responsible for most of the geohydrologic framework development and data-base management, and who will function as the GIS specialist.

Each staff member will be responsible for specific work elements in addition to the contribution of their respective chapter in the Professional Paper series. In addition to the RASA staff, it is expected that a senior-level hydrologist from the District Offices in Ohio and Indiana will work full-time on related subprojects to be determined during the first year of the study. Additional help will come from part-time, junior-level hydrologists and hydrologic technicians working directly with the Ohio-Indiana RASA staff, and from professors and graduate students from universities in Indiana and Ohio.

\section{Work and Report Schedule}

A planning stage and staffing period was started in the last quarter of fiscal year 1988 and is expected to last no longer than 1 year. The scheduled completion of the project is at the end of fiscal year 1993. The major project components and their expected times of completion are shown in figure 10. The times may vary according to project progress and difficulties encountered. 


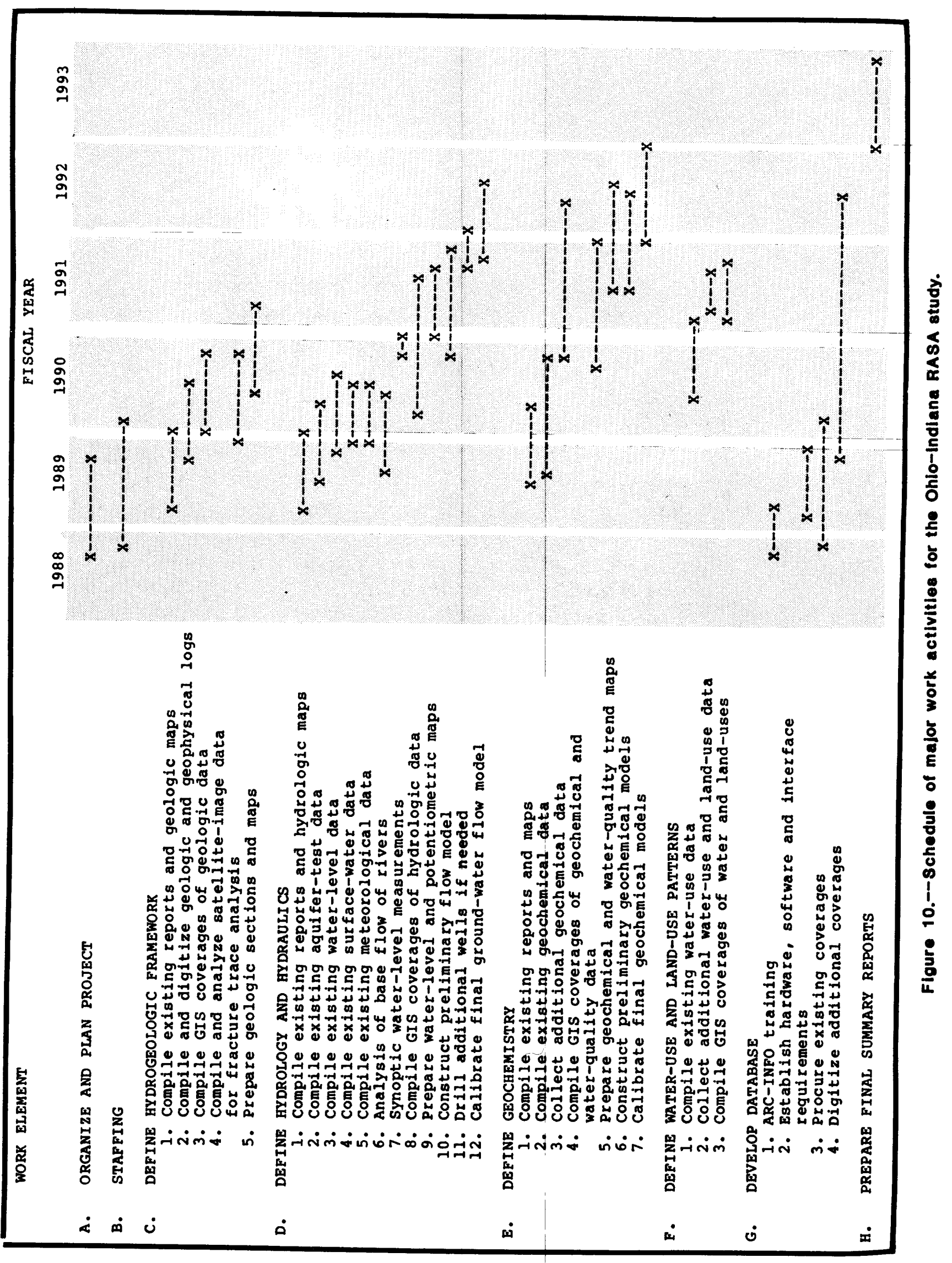




\section{REFERENCES CITED}

Arihood, L. D., 1982, Ground-water resources of the White River basin, Hamilton and Tipton Counties, Indiana: U.S. Geological Survey Water-Resources Investigations Report 82-48, 69 p.

Baker, D. B., 1983, Herbicide contamination in municipal water supplies of Northwestern Ohio: Tiffin, Ohio, Heidelberg College, 33 p.

Burns, M., Logan, S. M., and Steen, W. J., 1985, Map showing bedrock topography of the Teays Valley, eastern part, north-central Indiana: Ohio Geological Survey, Miscellaneous Map 44, 1 sheet, scale, 1:1,000,000

1985, Map showing bedrock topography of the Teays Valley, central part, northcentral Indiana: Ohio Geological Survey, Miscellaneous Map 43, 1 sheet, scale, $1: 1,000,000$

1985, Map showing bedrock topography of the Teays Valley, western part, northcentral Indiana: Ohio Geological Survey, Miscellaneous Map 42, 1 sheet, scale, $1: 1,000,000$

Fenneman, N. M., 1938, Physiography of Eastern United States: McGraw-Hill Book Co. Inc., New York., 714 p.

Flint, R. F., 1956, Glacial Geology and the Pleistocene epoch: John Wiley and Sons, New York, 589 p., $6 \mathrm{pl}$.

Flint, R. F., Colton, R. B., Goldthwait, R. P., and Wilman, H. B., 1959, Glacial map of the United States east of the Rocky Mountains: Geological Society of America, 1 pl., scale 1:750,000

Norris, S. E., 1969, The ground-water situation in Ohio: Ground Water, v. 7. no. 5, p. 25-32.

Norris, S. E., and Fiddler, R. E., 1971, Carbonate equilibria distribution and its relation to an area of high ground-water yield in northwest Ohio: U.S. Geological Survey Professional Paper 750-C, p. C202-C206.

1973, Availability of water from limestone and dolomite aquifers in southwest Ohio: U.S. Geological Survey Water-Resources Investigation 17-73, 46 p. 
Indiana Governor's Water Resource Study Commission, 1980, The Indiana water resource: availability, uses, and needs, $1508 \mathrm{p}$.

Ohio Department of Natural Resources, 1970, Ground water for planning in northwest Ohio-A study of carbonate rock aquifers: Ohio Water Plan Inventory Report Number 22, $63 \mathrm{p}$.

Planert, M, 1980, Ground-water availability near Fort Wayne, Allen County, Indiana: U.S. Geological Survey Water-Resources Investigations 80-34, 54 p.

Shaver, R.H. and others, 1986, Compendium of Paleozoic rock-unit stratigraphy in Indiana revision: Indiana Geological Survey Bulletin 59, 203 p.

Stout, W., 1941, Dolomites and limestones of western Ohio: Ohio Geological Survey Bulletin 42, $268 \mathrm{p}$.

Sun, R.J., 1984, Regional aquifer-system analysis program of the U.S. Geological Survey-summary of projects, 1978-84: U.S . Geological Survey Circular 1002, $264 \mathrm{p}$.

Todd, D. K., 1980, Ground-water hydrology, 2d ed.: New York, John Wiley and Sons, $535 \mathrm{p}$.

U.S. Department of Commerce, 1984a, 1982 Census of agriculture-Indiana State and County data: v. 1, pt 14, 443 p. 1984b, 1982 Census of agriculture-Ohio state and county data: v. 1, pl. 35, $431 \mathrm{p}$.

U. S. Environmental Protection Agency, 1976, National Interim Primary Drinking Water Regulations: Environmental Protection Agency, Office of Water Supply, 159 p.

U.S. House of Representatives. 1977, Report of Committee on Appropriations for the Department of the Interior and related agencies for fiscal year 1978: 95th Congress, First Session, House Report no. 95-392.

Wayne, W. J., 1956, thickness of drift and bedrock physiography of Indiana north of the Wisconsin glacial boundary: Indiana Department of Conservation-Geological Survey Report of Progress No. 7, 70 p., 1 plate, scale, 1:500,000. 